\title{
Physical and sensory attributes of fibre enriched cookies
}

\author{
K. Suma AND P.V. NANDinI
}

The study was designed to formulate fibre enriched cookies that contains sufficient nutrient (protein and fibre). The objectives of this research were to prepare fibre enriched cookies supplemented with rice bran and wheat bran at different proportion (10 to $50 \%$ ) and to assess their physical and sensory properties. Fibre enriched cookies were developed by incorporating rice bran, wheat bran and rice + wheat bran with refined wheat flour and other necessary ingredients. The recipe was standardized and evaluated for physical parameters and overall acceptability. It was observed that cookies prepared with 30 per cent incorporation of fibre was highly acceptable. The use of 30 per cent of fibre in the preparation of cookies is a useful strategy to optimize the consumption of food rich in functional ingredients.

Key Words : Fibre, Rice bran, Wheat bran, Sensory quality

How to cite this article : Suma, K. and Nandini, P.V. (2015). Physical and sensory attributes of fibre enriched cookies. Food Sci. Res. J., 6(2): 207-214.

K. SUMA, Department of Home Science, College of Agriculture, Vellayani THIRUVANANTHAPURAM (KERALA) INDIA

Associate Authors' :

P.V. NANDINI, Department of Home Science, College of Agriculture, Vellayani, THIRUVANANTHAPURAM (KERALA) INDIA 